Rev. Int. Contam. Ambie. 37, 455-462, 2021

https://doi.org/10.20937/RICA.53864

\title{
MUTATIONS IN radA ARE RESPONSIBLE FOR ACQUIRED RADIO-RESISTANCE IN AN Escherichia coli STRAIN
}

Mutaciones de $\mathrm{radA}$ son responsables de la radiorresistencia adquirida en una cepa de Escherichia coli

\begin{abstract}
David ALCÁNTARA DÍAZ ${ }^{1 *}$, Jorge Humberto SERMENT GUERRERO ${ }^{1}$, Gerardo AGUIRRE ESCALONA ${ }^{2}$ and Jorge Tonatiuh AYALA SUMUANO ${ }^{3}$
\end{abstract}

${ }^{1}$ Instituto Nacional de Investigaciones Nucleares, Carretera Federal México-Toluca s/n, La Marquesa, 52750 Ocoyoacac, Estado de México, México.

${ }^{2}$ Universidad Tecnológica del Valle de Toluca, km 7.5 Carretera del Departamento del Distrito Federal, Santa María Atarasquillo, 52044 Lerma, Estado de México, México.

${ }^{3}$ Instituto de Neurobiología, Universidad Nacional Autónoma de México, Boulevard Juriquilla 3001, Col. Juriquilla, 76230 Querétaro, Querétaro, México.

*Author for correspondence: david.alcantara@inin.gob.mx

(Received: January 2020; accepted: August 2020)

Key words: cyclic irradiation, bacterial adaptation, recombinant DNA repair.

\begin{abstract}
When bacteria are exposed to chronic or cyclic irradiation with ultraviolet (UV) light, it is observed that their resistance to this agent is increased by the selection of advantageous mutations under those conditions. UV light produces different damages in DNA, the repair of which is necessary to maintain the integrity of the genome. However, some damages can lead to such mutations when they are not properly repaired. In an earlier work, five subcultures of a wild-type Escherichia coli strain (PQ30) were cyclically irradiated with UV and different strains resistant to UV light and gamma radiation were obtained. In a preliminary mapping, different genes involved in their resistance to radiation were identified. In one of these strains, designated as IN801, the radA gene, the product of which is involved in recombinational DNA repair, was identified. In this work, cells from another wild-type strain (AB1157) were transformed with a plasmid (pUC19) that carries the radA gene from either PQ30 or IN801, in order to establish whether the radio-resistant phenotype can be transferred to a normal strain. Only cells that received the IN801 $\mathrm{radA}$ gene showed increased resistance to UV and gamma radiation. Further $\mathrm{radA}$ sequencing showed that the gene of IN801 acquired two-point mutations that replace two amino acids in the RadA protein, which most likely changed its enzymatic activities. These results confirm that radA participates in the radiation resistance of IN801.
\end{abstract}

Palabras clave: irradiación cíclica, adaptación bacteriana, reparación por recombinación del ADN.

\section{RESUMEN}

Cuando las bacterias se exponen a irradiación crónica o cíclica con luz ultravioleta (UV) se observa que su resistencia a este agente aumenta por la selección de mutaciones 
ventajosas en tales condiciones. La luz UV produce diferentes daños en el ADN cuya reparación es necesaria para mantener la integridad del genoma. Sin embargo, algunos daños pueden dar lugar a tales mutaciones cuando no son reparados de manera adecuada. En un trabajo anterior se irradiaron cíclicamente con UV cinco subcultivos de una cepa de Escherichia coli de tipo silvestre (PQ30) y se obtuvieron diferentes cepas resistentes a luz UV y a radiación gamma. En un mapeo preliminar se identificaron diferentes genes asociados con su resistencia a radiación. En una de esas cepas, designada como IN801, el gen $\mathrm{radA}$, cuyo producto interviene en la reparación por recombinación del ADN, fue identificado. En este trabajo se transformaron células de otra cepa de tipo silvestre (AB1157) con el plásmido (pUC19) que lleva el gen radA, ya sea de PQ30 o de IN801, con el propósito de establecer si el fenotipo radiorresistente puede ser transferido a una cepa normal. Únicamente las células que recibieron el gen $\mathrm{radA}$ de IN801 mostraron una mayor resistencia a radiación UV y gamma. La secuenciación adicional de radA de IN801 mostró que el gen adquirió dos mutaciones puntuales que reemplazan dos aminoácidos en la proteína RadA, lo cual muy probablemente cambió sus actividades enzimáticas. Estos resultados confirman que radA participa en la resistencia a radiación de IN801.

\section{INTRODUCTION}

During Darwinian adaptation, organisms with advantageous mutations are selected. Two factors are necessary for this process: genetic variability, given by spontaneous mutations within biological populations, and natural selection that acts on the individuals better adapted to the new environmental conditions. UV light is a type of radiation that has been omnipresent in nature and is thought to have had great importance in the evolution of life. UV is absorbed by nucleic acids producing several types of damage that interfere with DNA replication and transcription, giving rise to mutagenesis and cell killing. Several mechanisms have been developed along biological evolution to protect and repair genetic information from exposure to this and other genotoxic agents. These mechanisms can counter, for example, the lethal effects of solar UV light, which can cause severe genetic damage that in humans can lead to cancer. The study of adaptation to extreme conditions of UV incidence is of great scientific interest. For example, a decrease in the protective capacity of the ozone layer from solar UV rays or the colonization of environments with high incidence of $\mathrm{UV}$, such as the surface of Mars, is expected to produce an adaptation of living beings.

Escherichia coli can efficiently repair its genetic material (DNA) from damage induced by natural UV light or gamma radiation (Piette 1990, Livneh et al. 1993). However, the survival of this bacterium increases after repeated or chronic irradiation, indicating that the repair or protection of its genome was improved by a process of mutation and selection (Ewing 1995, Goldman and Travisano 2011, Byrne et al. 2014, Bruckbauer et al. 2019). In a previous work in which E. coli PQ30 was treated with 80 growth-irradiation cycles of UV light $(254 \mathrm{~nm})$, a derivative strain resistant to UV and gamma radiation designated as IN801 was isolated (Alcántara-Díaz et al. 2004). The UV resistance of this mutant, as determined by the survival at a dose of $100 \mathrm{~J} / \mathrm{m}^{2}$, increased more than 100 times when compared with the parent strain.

Preliminary mapping by gradient of transmission (Miller 1993) of the gene or genes affected, suggested that $\mathrm{radA}$ was probably involved (Alcántara-Díaz et al. 2004). The product of this gene participates in the late stages of recombinational repair (Beam et al. 2002). However, in view that the technique used in that preliminary mapping is not sufficiently accurate $( \pm 1.5 \mathrm{~min})$ (Miller 1993), the purpose of this work was to confirm this result in a more reliable way. In the first place, the $\mathrm{radA}$ genes from both the parent (PQ30) and derived IN801 strains were isolated and transferred to a wild type strain in order to see if radiation resistance can be transferred along with the $\mathrm{rad} A$ gene of IN801. The results clearly show that transfer of $\mathrm{radA}$ from IN801, but not from the parent strain PQ30, increases the survival to UV and gamma radiation of a wild type strain. In the second place, the sequencing of original and mutant $\mathrm{rad} A$ genes revealed the presence of two-point mutations in $\mathrm{radA}$ of IN801 that replace two amino acids in the mutant protein: valine for alanine and leucine for proline. 


\section{MATERIALS AND METHODS}

Strains used in this work are listed in table $\mathbf{I}$. Taq polymerase, restriction enzymes and T4 ligase were purchased from Fermentas. The rest of the chemicals used in this work were purchased from Sigma-Aldrich unless otherwise is indicated. Bacteria were grown in Luria broth (LB) $(\mathrm{NaCl} 10 \mathrm{~g}$, peptone biotryptase $10 \mathrm{~g}$, yeast extract $5 \mathrm{~g}$, per liter of distilled water) and 2YT (bacto tryptone $16 \mathrm{~g}$, yeast extract $10 \mathrm{~g}, \mathrm{NaCl} 5 \mathrm{~g}$, per liter of distilled water).

\section{Radiation survival}

Survival to UV and gamma radiation was determined in the following way: liquid cultures were grown overnight, diluted 50 -fold in fresh LB broth and incubated in a water bath shaker at $37{ }^{\circ} \mathrm{C}$ to mid-logarithmic phase $\left(2 \times 10^{8}\right.$ cells $\left./ \mathrm{mL}\right)$. They were subsequently centrifuged and suspended in $200 \mathrm{mM}$ phosphate buffer. Radiation treatments were performed at room temperature either in a Gammacell ${ }^{60} \mathrm{Co}$ source, at a rate of $10 \mathrm{~Gy} /$ minute, or by using a $15 \mathrm{~W}$ $\mathrm{Hg}$ vapor UV germicidal lamp, calibrated at a dose rate of $10 \mathrm{~J} / \mathrm{m}^{2} / \mathrm{s}$ with a UVP meter model UVX-25. After radiation treatment, cultures were diluted, spread over LB agar and incubated overnight at $37^{\circ} \mathrm{C}$ for viable count. Survival curves represent the average of three experiments and standard deviations are included.

\section{DNA extraction}

DNA was extracted from strains PQ30 and IN801 as follows: $1 \mathrm{~mL}$ of an overnight culture was centrifuged for $30 \mathrm{~s}$ at $12000 \mathrm{rpm}$ and all but $50 \mu \mathrm{L}$ of the supernatant was discarded. Pellet was resuspended and $5 \mu \mathrm{L}$ of RNase $(10 \mathrm{mg} / \mathrm{mL})$ and $150 \mu \mathrm{L}$ of lysis solution (10 mM Tris-HCl pH 8.0, 1 mM EDTA, $0.5 \%$ SDS) were added. Samples were incubated for $5 \mathrm{~min}$ at room temperature and then
$150 \mu \mathrm{L}$ of $3 \mathrm{M}$ sodium acetate were added, gently mixed and centrifuged at $12000 \mathrm{rpm}$ for $3 \mathrm{~min}$. Supernatant was transferred to a fresh tube and $300 \mathrm{~mL}$ of phenol:chloroform:isoamyl alcohol were added, vortexed for 10 seconds and centrifuged for $5 \mathrm{~min}$. Then, aqueous phase was transferred to a fresh tube and $1 \mathrm{~mL}$ of cold absolute ethanol was added, gently mixed by inversion and centrifuged again for $10 \mathrm{~min}$ under the same conditions. Supernatant was carefully discarded, and the bottom suspended in $1 \mathrm{~mL}$ of $70 \%$ ethanol at room temperature, further centrifuged and supernatant carefully decanted. Tubes were dried at $37^{\circ} \mathrm{C}$ for at least $1 \mathrm{~h}$. Twenty micro-litters of TE buffer (Tris $10 \mathrm{mM}$, EDTA $1 \mathrm{mM}, \mathrm{pH}$ 8.1) were added and pipetted up and down repeatedly to dissolve the DNA (Sambrook et al. 1989).

\section{Polymerase chain reaction}

The $\operatorname{rad} A$ gene was amplified by PCR from both PQ30 and IN801-1 genomic DNA. The initiators were designed by us with the Primer Designer Tool program from Applied Biosystems; the sequences were: 5'-GGCACAGCATTAACGAGGTA and 5'-TGCTTGATGGCAGTTTTCAG. Primers were designed to amplify the gene without the promoter and for this reason it is necessary to add IPTG to the growth medium, so that plasmid $\mathrm{radA}$ is expressed. Thermal cycler parameters were set as follows: denaturing: $94{ }^{\circ} \mathrm{C}$ for $1 \mathrm{~min}$; annealing: $52{ }^{\circ} \mathrm{C}$ for 1 min; extension: $72{ }^{\circ} \mathrm{C}$ for 1 min $(35$ cycles $)$ and a final extension time of $10 \mathrm{~min}$. PCR products were charged into a $1 \%$ agarose gel, electrophoresed for $1 \mathrm{~h}$ at $100 \mathrm{~V}$ and then bands corresponding to the amplified $\mathrm{rad} A$ gene were cut out and purified using the Ultrafree-DA system (Millipore).

\section{Plasmid construction}

Plasmid pUC19 has the bla gene that confers resistance to ampicillin, so it was not possible to

TABLE I. BACTERIAL STRAINS.

\begin{tabular}{|c|c|c|}
\hline Strain & Genotype & Source/reference \\
\hline PQ30 & 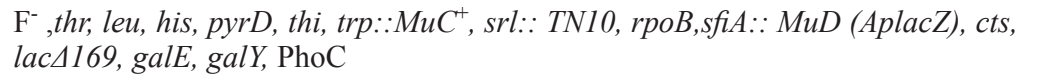 & $\begin{array}{l}\text { Quillardet and Hofnung } \\
1985\end{array}$ \\
\hline IN801-1 & Radio resistant mutant derived from PQ30 after 80 cycles of UV light exposition & $\begin{array}{l}\text { Alcántara-Diaz et al. } \\
2004\end{array}$ \\
\hline AB1157 & $\begin{array}{l}\text { thr-1, araC14, leuB6(Am), } \Delta(\text { gpt-proA) 62, lacY1, tsx-33, qsr'-0, glnV44(AS), } \\
\text { galK2(Oc), LAM-, Rac-0, hisG4(Oc), rfbC1, mgl-51, rpoS396(Am), rpsL31(strR), } \\
\text { kdgK51, xylA5, mtl-1, argE3(Oc), thi-1 }\end{array}$ & Allman et al. 1991 \\
\hline
\end{tabular}


select the transformants directly in PQ30, which is already resistant to this antibiotic. For this reason, it was needed to insert the new plasmids in AB1157, that in addition to being sensitive to ampicillin, is a wild strain in terms of repair mechanisms and an ancestor of PQ30 (Quillardet and Hofnung 1985). Plasmid pUC19 was purified by alkaline minipreps (Sambrook et al. 1989), suspended in autoclaved milliQ water and then restricted using SmaI for 18 $\mathrm{h}$ at $30^{\circ} \mathrm{C}$, according to the supplier's indications. Restriction was verified by electrophoresis.

Taq polymerase was used in PCR, so the amplified products carry protruding A' at each end, and since Smal produces blunt ends, an additional step was included to insert a T' at both ends of linearized pUC19 (Zhou and Gómez-Sánchez 2000). To do that, $83 \mu \mathrm{L}$ of restricted pUC19 $(75 \mu \mathrm{g} / \mathrm{mL})$ were mixed with $10 \mu \mathrm{L}$ of $10 \times$ Taq buffer, $5 \mu \mathrm{L}$ of $\mathrm{MgCl} 2$ $(50 \mu \mathrm{M}), 1 \mu \mathrm{L}$ of dTTp $(100 \mu \mathrm{M})$ and $1 \mu \mathrm{L}$ of Taq polymerase and incubated for $2 \mathrm{~h}$ at $72^{\circ} \mathrm{C}$. Plasmid was purified afterwards by precipitation with ethanol and suspended in $40 \mu \mathrm{L}$ of DNAse-free water.

Ligation of the amplified $\mathrm{radA}$ genes was performed by T4 ligase according to the supplier's indications. Fifteen micro-litters of the restricted plasmid suspension, $2 \mu \mathrm{L}$ of reaction buffer, $2 \mu \mathrm{L}$ of amplified $\mathrm{radA}$ and $1 \mu \mathrm{L}$ of ligase were mixed in a microtube and incubated for $18 \mathrm{~h}$ at $16^{\circ} \mathrm{C}$.

\section{Bacterial transformation}

The AB1157 strain was transformed with the newly constructed plasmids carrying the $\mathrm{rad} A$ genes from either IN801 or PQ30. An aliquot of an overnight culture was diluted 1/100 in LB broth, incubated at $37^{\circ} \mathrm{C}$ to an $\mathrm{OD}_{600}$ of 0.2 , then chilled and kept on ice for all subsequent steps. The culture was then washed with ice-cold $10 \%$ glycerol for at least five times and suspended in $1 / 100$ of the original volume of $10 \%$ glycerol. An aliquot of $20 \mathrm{~mL}$ was mixed with $1 \mathrm{~mL}$ of the plasmid, pipetted into a cold electroporation cuvette (0.2-cm gap) and electroporated at $12.5 \mathrm{KV} /$ $\mathrm{cm}$ (field strength), $200 \Omega$ (resistor), and $25 \mu \mathrm{F}$ (capacitor) (Wu et al. 2010). Bacteria were immediately suspended in $1 \mathrm{~mL}$ of $2 \mathrm{YT}$ broth, incubated for $1 \mathrm{~h}$ at $37^{\circ} \mathrm{C}$, plated on LB with ampicillin $(20 \mu \mathrm{g} / \mathrm{mL})$ and incubated overnight at $37^{\circ} \mathrm{C}$. Several colonies were recovered, cultured in LB broth, tested for ampicillin resistance and the presence of the plasmid was checked by alkaline extraction. To assess radiation survival, transformed bacteria were cultured in the presence of IPTG $(50 \mu \mathrm{M})$ and exposed to either gamma or UV radiation as stated above.

\section{Analysis of genetic changes}

Amplified $\mathrm{rad} A$ from both PQ30 and IN801 were sequenced by Sanger's method using the BigDye v3.1 kit (Applied Biosystems) and the ABI310 sequencer. The number of the $\mathrm{radA}$ sequence against which the mutated gene was compared is EG11296. The amino acid sequences were determined by the EMBOSS-Transeq facility from The European Bioinformatics Institute (EMBL-EBI; http://www.ebi. ac.uk). Nucleotide and amino acid sequences were compared by means of the CLUSTAL W program and predictions of 3D protein structures were obtained by means of the I-Tasser server (Zhang 2008, Ambrish et al. 2010, Jianyi et al. 2015, Yang and Zhang 2015).

\section{RESULTS}

Once amplified and purified, $\mathrm{radA}$ from both wild type strain PQ30 and its derivative IN801 were inserted by TA cloning into the plasmid pUC19, previously linearized by the restriction enzyme Smal specific for the sequence 5'-CCCGGG-3', which results in blunt ends. However, in view that the products resulting from PCR amplification have A' ends, it was necessary to employ a variant of PCR technique adding only thymine in order to have overhangs T' needed for the recircularization of the plasmid. Success in construction was verified by gel electrophoresis in which a single band with the molecular weight corresponding to the plasmid plus the insertion of $\mathrm{rad} A$ was observed. This band was cut, cleaned and used to transform the strain AB1157 of $E$. coli. Transformed cells were selected by ampicillin and the presence of the plasmid was confirmed by extraction and gel electrophoresis (data not shown).

Survival of the transformed bacteria with $\mathrm{radA}$ from both PQ30 and IN801 was then evaluated for $\mathrm{UV}$ and gamma radiation. Since the insertion of $\mathrm{radA}$ took place in a site controlled by an operator of the gen $l a c Z$, it was necessary to incubate the cells in the presence of IPTG. Figures $\mathbf{1}$ and $\mathbf{2}$ show a significant difference in survival between the two types of AB1157 transformants to both UV and gamma radiation, suggesting that $\mathrm{radA}$ from IN801 confers more radiation resistance to this strain.

By DNA sequencing, two base substitutions were found in $\mathrm{radA}$ of IN801. In both cases the substitutions were $\mathrm{T}$ for $\mathrm{C}$ replacing alanine for valine and proline for leucine in the positions 218 and 267 of protein RadA (Table II). Tridimensional modeling of mutant RadA protein by means of the I-Tasser server (Zhang 2008), shows structural differences from the original protein (Fig. 3). 
Survival to UV light of transormed AB1157 strains

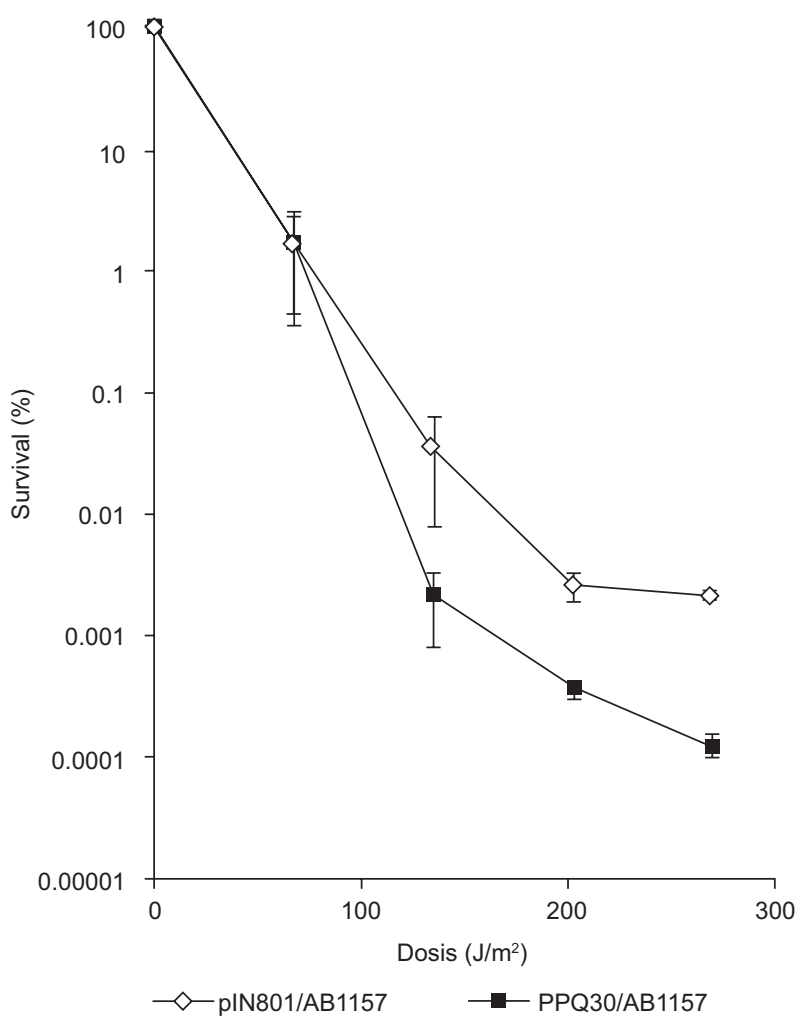

Fig. 1. Survival curves to UV light of the E. coli $\mathrm{AB} 1157$ strain transformed either with the plasmid bearing the original $\mathrm{radA}$ from $\mathrm{PQ} 30$ or the plasmid with the mutated $\mathrm{radA}$ from IN801.
Survival to gammalight of transormed AB1157

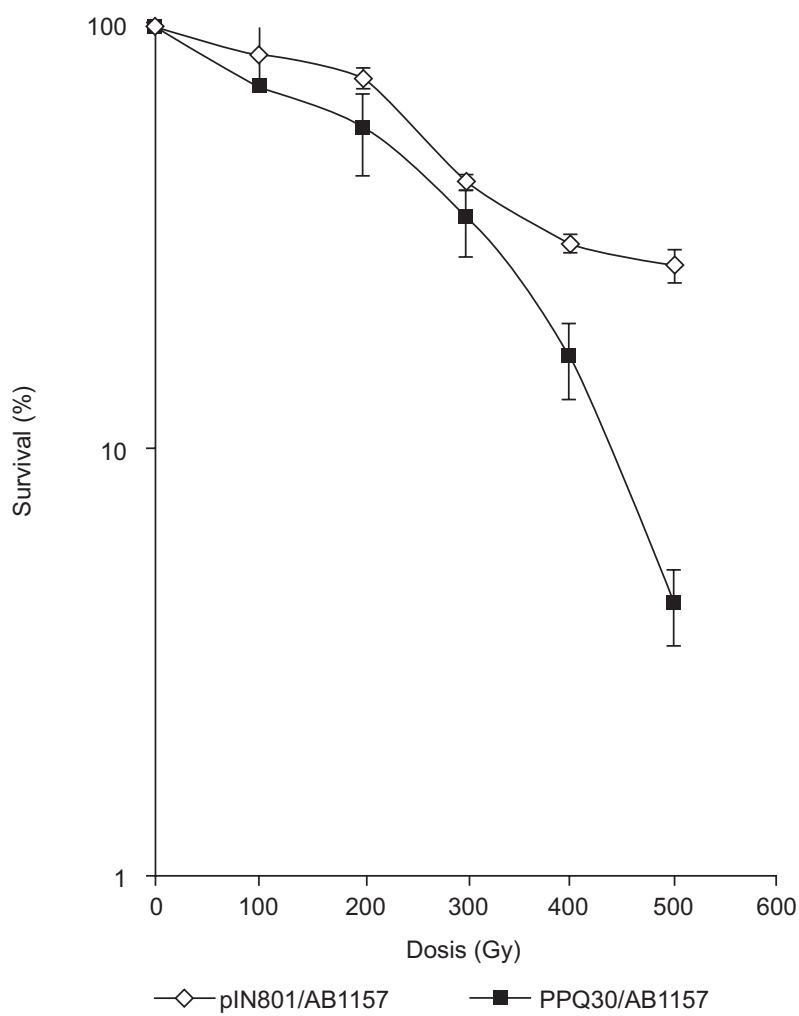

Fig. 2. Survival curves to gamma radiation of E. coli $\mathrm{AB} 1157$ strain transformed either with the plasmid bearing the original $\mathrm{radA}$ from PQ30 or the plasmid with the mutated $\operatorname{rad} A$ from $\mathrm{IN} 801$.

TABLE II. AMINO ACID SEQUENCES OF BOTH ORIGINAL AND MUTANT RadA PROTEINS.

\begin{tabular}{ll}
\hline Original RadA from & VAKAPKRAFVCNECGADYPRWQGQCSACHAWNTITEVRLAASPMVARNERLSGYAGSAGV \\
PQ30 & AKVQKLSDISLEELPRFSTGFKEFDRVLGGGVVPGSAILIGGNPGAGKSTLLLQTLCKLAQQM \\
& KTLYVTGEESLQQVAMRAHRLGLPTDNLNMLSETSIEQICLIAEEEQPKLMVIDSIQVMHMAD \\
& VQSSPGSVAQVRETAAYLTRFAKTRGVAIVMVGHVTKDGSLAGPKVLEHCIDCSVLLDGDAD \\
& SRFRTLRSHKNRFGAVNELGVFAMTEQGLREVSNPSAIFLSRGDEVTSGSSVMVVWEGTRPL \\
& LVEIQALVDHSMMANPRRVAVGLEQNRLAILLAVLHRHGGLQMADQDVFVNVVGGVKVTET \\
& SADLALLLAMVSSLRDRPLPQDLVVFGEVGLAGEIRPVPSGQERISEAAKHGFRRIVPAANV \\
& PKKAPEGMQIFGVKKLSDALSVFDDL \\
\hline \multirow{2}{*}{ Mutant RadA from } & VAKAPKRAFVCNECGADYPRWQGQCSACHAWNTITEVRLAASPMVARNERLSGYAGSAGV \\
& AKVQKLSDISLEELPRFSTGFKEFDRVLGGGVVPGSAILIGGNPGAGKSTLLLQTLCKLAQQM \\
& KTLYVTGEESLQQVAMRAHRLGLPTDNLNMLSETSIEQICLIAEEEQPKLMVIDSIQVMHMAD \\
& VQSSPGSVAQVRETAAYLTRFAKTRGVAIVMAGHVTKDGSLAGPKVLEHCIDCSVLLDGDAD \\
& SRFRTLRSHKNRFGAVNEPGVFAMTEQGLREVSNPSAIFLSRGDEVTSGSSVMVVWEGTRPL \\
& LVEIQALVDHSMMANPRRVAVGLEQNRLAILLAVLHRHGGLQMADQDVFVNVVGGVKVTET \\
& SADLALLLAMVSSLRDRPLPQDLVVFGEVGLAGEIRPVPSGQERISEAAKHGFRRAIVPAANV \\
& PKKAPEGMQIFGVKKLSDALSVFDDL
\end{tabular}



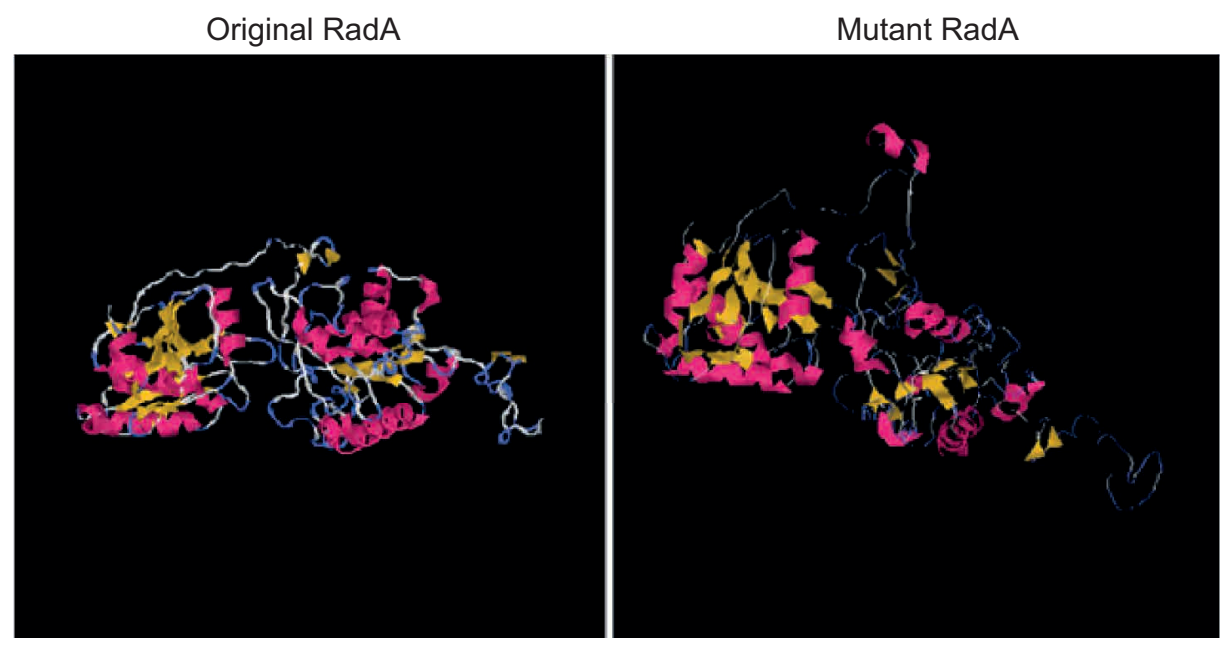

Fig. 3. Comparison of 3D-structures of RadA proteins from E. coli $\mathrm{PQ} 30$ original (left) and IN801 mutant (right).

\section{DISCUSSION}

The strain IN801 was obtained as part of a survey about the way distinct $E$. coli populations, derived from the same parent strain evolve under the environmental stress of increasing doses of UV light (Alcántara-Díaz et al. 2004). Preliminary gene mapping suggested that around minute 98.5 of the bacterial chromosome, there was a gene involved in the radiation resistance of this derivative. Since the nearest gene related to DNA repair is $\mathrm{radA}$ at minute 99.6 , it was assumed that it was involved. The data presented in this work confirm that $\mathrm{radA}$ plays a role in the radiation resistance of IN801.

Gene $\mathrm{rad} A$ was first identified in $E$. coli due to the sensitivity to UV light, X-rays and methyl methanesulfonate of strains defective in this gene (Diver et al. 1982). Subsequently, Sargentini and Smith (1986) observed that along with other genes, it participates in the repair of DNA double strand breaks induced by exposure of the cells to UV, gamma radiation or chemical genotoxic agents. In addition to $\operatorname{rad} A$, other genes like $\operatorname{rec} A, \operatorname{rec} B, C, D, \operatorname{rec} G$ and the $\operatorname{ruv} A, B$, $C$ complex, participate in the repair of this kind of lesion (Beam et al. 2002).

Bacterial $\mathrm{rad} A$ is a paralog of $\operatorname{rec} A$ and therefore both genes have some similarity. However, the RadA protein cannot carry out the step of strand exchange during homologous recombination or recombinational repair, a step exclusively catalyzed by RecA (Cooper and Lovett 2016). RadA protein possesses 4 well-defined domains that confer different enzymatic activities (Fig. 4). In the N-terminal domain is a putative Zinc finger similar to the zinc fingers of other DNA repair enzymes. A second domain shows homology with RecA, including the Walker A and Walker B boxes typical of ATPase's. Next is a region known as KNRFG that exhibits a strong homology with the gene 65 of the mycobacteriophage D29, whose product has been shown to act as a DNA exonuclease that removes 3' strands from forked structures leaving 5' overhangs (Giri et al. 2009). Finally, the C-terminal region has some similarity to the bacterial Lon protease.

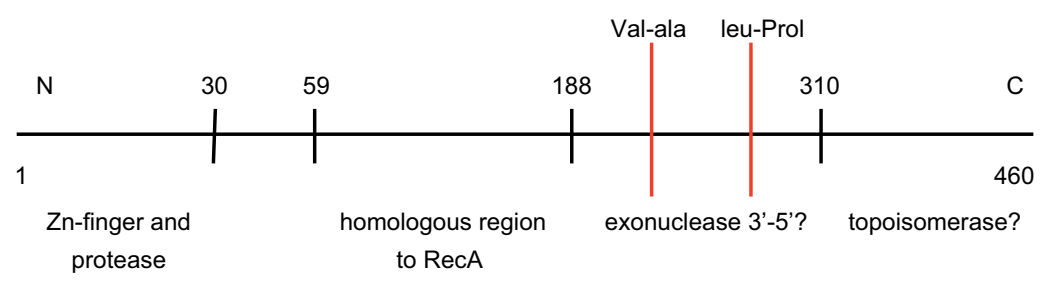

Fig. 4. Scheme of the RadA protein (not to scale), showing different domains and location of two substitutions (in red) in the mutant protein. 
It has been proposed that RadA protein has a role in processing intermediates of RecA-dependent bacterial recombination, either in branch migration of heteroduplex DNA formed after strand invasion carried out by RecA, or in the resolution of Holliday junctions at the final steps of recombination (Cooper and Lovett 2016). The two amino acid substitutions identified in the RadA protein reported in this work are located at positions 218 and 267 of the RadA protein, inside the aforementioned KNRFG region (Fig. 4).

Because both substitutions are in the region that presumably confers exonuclease activity to RadA, it may be altered in the mutant protein. The 3D structures of both original and mutant RadA proteins (Fig. 3) show important conformational differences that may cause distinct DNA interacting properties. Unfortunately, the available data do not allow to know in what way this enzymatic activity is modified but there are two alternatives. One is that the 3 '-5'exonuclease activity has been suppressed or reduced in the IN801 mutant, so that 5' overhangs, possibly generated by other exonucleases, remain available to form RecA nucleofilaments that subsequently invade homologous DNA duplex during recombinational repair. The other alternative is the opposite: that mutant RadA protein has a more efficient exonuclease activity, what would lead to a repair mechanism reminiscent of the extended synthesis-dependent strand annealing (ESDSA) present in the highly resistant to ionizing radiation and desiccation Deinococcus radiodurans (Zahradka et al. 2006, Slade et al. 2009). This repair mechanism is dependent on $\operatorname{rad} A$ and begins with an initial extensive exonucleolytic degradation of DNA fragments, generating single stranded overhangs that are extensively elongated by repair synthesis dependent on polymerase I. In support of this idea is the fact that strain IN801 is also more resistant to gamma radiation, namely at high doses, suggesting that its mechanism of DNA repair is more efficient as the more fragmented the chromosome is. This last alternative is more consistent with the dominance observed when both proteins are present simultaneously, as in AB1157 transformed with pUC19 carrying $\mathrm{rad} A$ from IN801. Although the results presented here demonstrate that the $\mathrm{rad} A$ gene participates in the increased UV and gamma survival of IN801, there is something that remains unclear: the radiation resistance of $\mathrm{AB} 1157$ transformed with mutant $\operatorname{rad} A$, is not as high as it is in IN801, which may be because there are other changes in this strain that have not been explored.

\section{REFERENCES}

Alcántara-Díaz D., Breña-Valle M. and Serment-Guerrero J. (2004). Divergent adaptation of Escherichia coli to cyclic ultraviolet light exposures. Mutagenesis 19 (5), 349-354. https://doi.org/10.1093/mutage/geh039

Allman R., Schjerven T. and Boye E. (1991). Cell cycle parameters of Escherichia coli K12. J. Bacteriol. 173 (24), 7970-7974. https://doi.org/10.1128/ jb.173.24.7970-7974.1991

Ambrish R., Alper K. and Yang Z. (2010). I-TASSER: A unified platform for automated protein structure and function prediction. Nat. Protoc. 5, 725-738. https:// doi.org/ https://doi.org/10.1038/nprot.2010.5

Beam C.E., Saveson C.J. and Lovett S.T. (2002). Role for $\mathrm{radA} / \mathrm{sms}$ in recombination intermediate processing in Escherichia coli. J. Bacteriol. 184 (24), 6836-6844. https://doi.org/10.1128/JB.184.24.6836-6844.2002

Byrne R.T., Klingele A.J., Cabot E.L., Schackwitz W.S., Martin J.A., Martin J., Wang Z., Wood E.A., Pennacchio C., Pennacchio L.A., Perna N.T., Battista J.R. and Cox M.M. (2014). Evolution of extreme resistance to ionizing radiation via genetic adaptation of DNA repair. eLife 2014 (3), e01322. https://doi.org/10.7554/eLife.01322

Bruckbauer S.T, Joseph D., Trimarco J.D, Martin J., Bushnell B., Senn K.A, Schackwitz W., Lipzen A., Blow M., Wood E.A., Culberson W.S., Pennacchio C. and Cox M.M. (2019). Experimental evolution of extreme resistance to ionizing radiation in Escherichia coli after 50 cycles of selection. J. Bacteriol. 201 (8), 3486-3498. https://doi.org/10.1128/JB.00784-18.

Cooper D.L. and Lovett S.T. (2016). Recombinational branch migration by the $\mathrm{radA} / \mathrm{Sms}$ paralog of RecA in Escherichia coli. eLife 2016 (5), e10807. https:// doi.org/10.7554/eLife.10807

Diver W.P., Sargentini N.J. and Smith K.C. (1982). A mutation (radA100) in Escherichia coli that selectively sensitizes cells grown in rich medium to X-or UV-radiation, or methyl methanesulphonate. Int. J. Radiat. Biol. Re. 42, 339-346. https://doi.org/ https:// doi.org/10.1080/09553008214551251

Ewing D. (1995). The directed evolution of radiation resistance in Escherichia coli. Biochem. Bioph. Re. Co. 216, 549-553. https://doi.org/10.1006/bbrc.1995.2657

Giri N., Bhowmik P., Bhattacharya B., Mitra M. and Das Gupta S.K. (2009). The mycobacteriophage D29 gene 65 encodes an early-expressed protein that functions as a structure-specific nuclease. J. Bacteriol. 191 (3), 959-967. https://doi.org/10.1128/JB.00960-08

Goldman R.P. and Travisano M. (2011). Experimental evolution of ultraviolet radiation resistance in Escherichia coli. Evolution 65 (12), 3486-3498. https://doi. org/ https://doi.org/10.1111/j.1558-5646.2011.01438.x 
Jianyi Y., Renxiang Y., Ambrish R., Dong X., Jonathan P. and Yang Z. (2015). The I-TASSER Suite: Protein structure and function prediction. Nat. Methods 12, 7-8. https://doi.org/ https://doi.org/10.1038/nmeth.3213

Livneh Z., Cohen-Fix O., Skaliter R. and Elizur T. (1993). Replication of damaged DNA and the molecular mechanism of ultraviolet light mutagenesis. Crit. Rev. Biochem. Mol. 28, 465-513. https://doi.org/https://doi. org/10.3109/10409239309085136

Miller J.H. (1993). A short course in bacterial genetics: A laboratory manual and handbook for Escherichia coli and related bacteria. Trends. Biochem. Sci. Library Compendium 18, 193.

Piette J. (1990). Nucleic acids, DNA repair, photomutagenesis. J. Photoch. Photobio. B 5, 275-276. https:// doi.org/10.1016/1011-1344(90)80015-p

Quillardet P. and Hofnung M. (1985). The SOS chromotest, a colorimetric bacterial assay for genotoxins: Procedures. Mutat. Res. 147, 65-78. https://doi.org/ https://doi.org/10.1016/0165-1161(85)90020-2

Sambrook J., Fritsch E.F. and Maniatis T. (1989). Molecular cloning: A laboratory manual. Cold Spring Harbor Laboratory Press, NY, USA.

Sargentini N.J. and Smith K.C. (1986). Quantitation of the involvement of the rec $A, r e c B$, rec $C$, recF, recJ, $\operatorname{rec} N$, lexA, $\operatorname{rad} A, \operatorname{rad} B, u v r D$, and $u m u C$ genes in the repair of X-ray-induced DNA double-strand breaks in Escherichia coli. Radiat. Res. 107, 58-72. https://doi. org/ https://doi.org/10.2307/3576850

Slade D., Lindner A.B., Paul G. and Radman M. (2009). Recombination and replication in DNA repair of heavily irradiated Deinococcus radiodurans. Cell 136, 1044-1055. DOI 10.1016/j.cell.2009.01.018

Wu N., Matand K., Kebede B., Acquaah G. and Williams S. (2010). Enhancing DNA electrotransformaion efficiency in Escherichia coli DH10B electrocompetent cells. Electron. J. Biotechno. 13, 21-22. https://doi. org/10.2225/vol13-issue5-fulltext-11

Yang J. and Zhang Y. (2015). I-TASSER server: New development for protein structure and function predictions. Nucleic Acids Res. 43, 174-181. https://doi.org/ https://doi.org/10.1093/nar/gkv342

Zahradka K., Slade D., Bailone A., Sommer S., Averbeck D., Petranovic M., Lindner A.B. and Radman M. (2006). Reassembly of shattered chromosomes in Deinococcus radiodurans. Nature 443 (5), 569-573. https://doi.org/10.1038/nature05160

Zhang Y. (2008). I-TASSER server for protein 3D structure prediction. BMC Bioinformatics 9, 40. https://doi.org/ https://doi.org/10.1186/1471-2105-9-40

Zhou M.Y. and Gómez-Sánchez C.E. (2000). Universal TA cloning. Curr. Issues Mol. Biol. 2, 1-8. 